\title{
CHRONOLOGY OF WETLAND HYDROLOGICAL DYNAMICS AND THE MESOLITHIC- NEOLITHIC TRANSITION ALONG THE LOWER SCHELDT: A BAYESIAN APPROACH
}

\author{
Jeroen Verhegge ${ }^{1,2} \cdot$ Tine Missiaen $^{3} \cdot$ Mark Van Strydonck $^{4} \cdot$ Philippe Crombé $^{1}$
}

\begin{abstract}
The Mesolithic-Neolithic transition in the wetland margins of the southern North Sea basin occurred well over a millennium after the transition in neighboring loess regions. This article investigates the possible role of hydrological dynamics in the presence of the last hunter-gatherer-fishermen in these wetland regions. A Bayesian modeling approach is used to integrate stratigraphic information and radiocarbon dates both from accurately datable archaeological remains and key horizons in peat sequences in the Scheldt floodplain of northwestern Belgium. This study tests whether the Swifterbant occupation of the study area was contemporaneous with hiatuses in peat growth caused by organic clastic sedimentation due to increased tidal influences and local groundwater rise. The results suggest that the appearance of this culture followed shortly after the emergence of a brackish tidal mudflat landscape replacing a freshwater marsh.
\end{abstract}

\section{INTRODUCTION}

In the last decade, large-scale salvage excavations in the lower Scheldt River basin have revealed at least three well-preserved settlements (nr 4,7, and 8 on Figure 1) dating back to the Mesolithic-Neolithic transition (Crombé 2005; Sergant et al. 2006; Crombé et al. 2009). These sites have been attributed to the Swifterbant culture (Crombé et al. 2011b), which indicates a gradual adaptation from a hunter-fisher-gatherer economy to an extended broad spectrum economy that involved cattle-breeding and small-scale cereal cultivation (Raemaekers 1999; Louwe Kooijmans 2010). These wetland sites constitute key sites in the study of the neolithization of the sandy lowlands along the southern North Sea basin. A series of radiocarbon dates obtained from carbonized plant remains (seeds and fruits) and charcoal from surface hearths and hearth dumps situate these transitional sites in the second half of the 7th millennium cal BP, specifically between $\sim 6550$ and $\sim 5950$ cal BP (Boudin et al. 2009; Crombé et al. 2011b). In order to reconstruct the environment in which this economic transition took place, intensive multiproxy paleoecological investigations have been conducted on peat sequences from these sites and within their immediate vicinities. This article presents the ${ }^{14} \mathrm{C}$ dates from these sequences in order to investigate the relationship between the archaeological occupation of the dated sites and the development of a peat marsh and occurrence of a tidal regime in the region.

\section{AIMS}

This study will focus on the following:

1. Dating of the peat development using ${ }^{14} \mathrm{C}$ dates from the basis of the basal peat at varying elevations and landscape positions in the floodplain surrounding two archaeological sites of the Swifterbant culture to derive a regional time-depth model.

2. Dating the beginning and ending of a first flooding period, using dates from in situ peat related to intercalating organic tidal clay deposits.

3. Relating $\# 1$ and $\# 2$ to ${ }^{14} \mathrm{C}$ dates directly attributable to the occupation of the Final Mesolithic (FM)/Early Neolithic (EN) Swifterbant sites of Doel Deurganckdok sector B and M (nr 8 and 4 in Figure 1).

1. Dept. of Archaeology, Ghent University, Sint-Pietersnieuwstraat 35, B-9000 Ghent, Belgium.

2. Corresponding author. Email: Jeroen.Verhegge@ugent.be.

3. Renard Centre for Marine Geology, Dept. of Geology \& Soil Science, Ghent University, Krijgslaan 281 S8, B-9000 Ghent, Belgium.

4. ${ }^{14} \mathrm{C}$ laboratory, Royal Institute for Cultural Heritage, Jubelpark 1, B-1000 Brussels, Belgium.

Proceedings of the Radiocarbon and Archaeology 7th International Symposium

Ghent, Belgium, April 2013 | Edited by Mark Van Strydonck, Philippe Crombé, and Guy De Mulder

(C) 2014 by the Arizona Board of Regents on behalf of the University of Arizona 


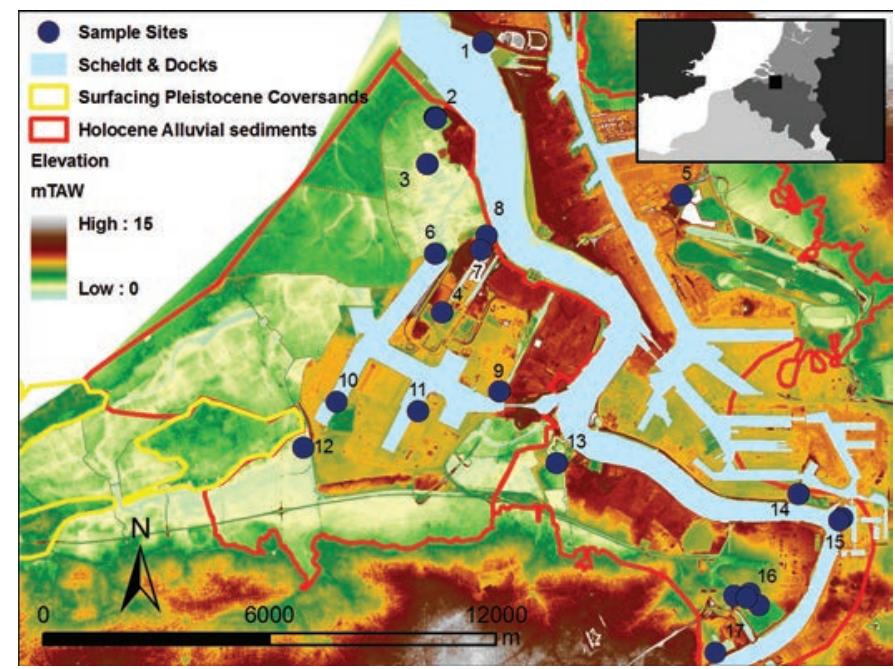

Figure 1 Site locations of dated samples (names and bibliographic references in Appendices 1 and 2) in the study area (background elevation data from AGIV).

\section{PALEOENVIRONMENTAL SITUATION}

The two Swifterbant sites studied are situated on the left bank of the lower Scheldt in northwestern Belgium. They were discovered in the municipality of Doel between 2000 and 2003, during the construction of the Deurganck dock in Antwerp Harbor (Crombé 2005; Crombé et al. 2009). Both sites are situated on top of relatively narrow (cover)sand ridges at a depth of $0.5-1.0 \mathrm{~m}$ below national ordnance level (TAW = mean low water tide level in Oostende).

Over the past few decades, peats and organic clastic sediments have been sampled and analyzed on different locations both on- and offsite in the lower Scheldt Valley for geological and paleoecological investigation (pollen, seeds and fruits, diatoms, mollusks, etc.), allowing detailed regional paleoenvironmental reconstructions (Bastiaens et al. 2005; Gelorini et al. 2006; Deforce 2011; Van Neer et al. 2013). Awaiting better Belgian geological nomenclature for the Antwerp peats (Bogemans 1997; Gullentops et al. 2001; Baeteman 2004) and for ease of reference to older literature, the established nomenclature will be used lithostratigraphically without implying a fluctuating sea-level rise (Figure 2).

As soon as the local groundwater table reached the surface of the Pleistocene (cover)sands, eutrophic basal peat started to develop in a fen carr environment in the depressions. It started in the lowest depressions and developed to cover the entire area and eventually even the highest dunes, which were occupied by hunter-fisher-gatherer societies.

Locally, peat growth was interrupted by flooding of brackish water (formerly known as the Calais transgressions), which led to the deposition of organic tidal clastic sediments ("Calais deposits"). Pollen samples indicate that the region was situated in a transitional zone between brackish and freshwater environments (Gelorini et al. 2006; Deforce 2011). The botanical and zoological evidence recovered from contemporaneous Swifterbant hearths (Deforce et al. 2013; Van Neer et al. 2013) at some localities suggests freshwater conditions, while at other locations evidence of a brackish water environment suggests sandy elevations within the floodplain to be covered with an alluvial hardwood forest, only incidentally touched by inundations. 


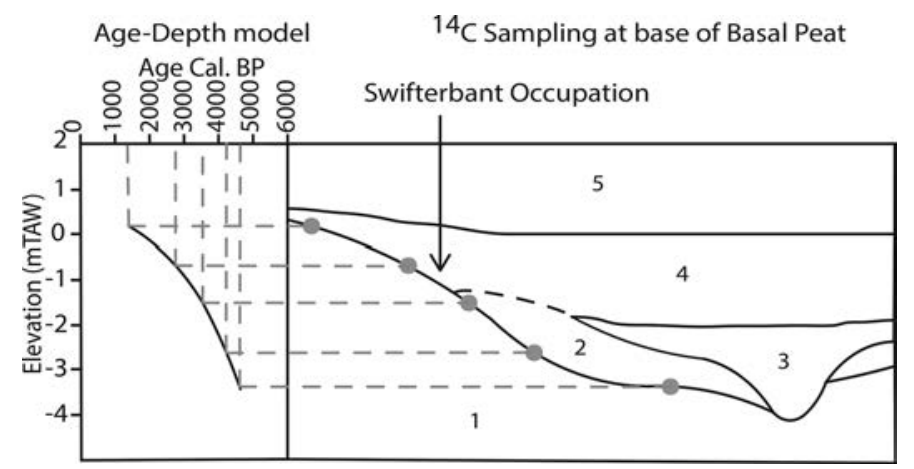

Figure 2 Basic principle of mean high water (MHW) reconstruction and applied lithostratigraphic terminology (1: Pleistocene sands; 2: basal peat; 3: Calais deposits; 4: Holland peat; 5: Dunkirk deposits).

Aside from the continuous relative sea-level (RSL) rise, this flooding was caused by a combination of the local post-Pleistocene topography, the availability of marine and fluvial sediments in combination with a negative sedimentary balance (Beets and van der Spek 2000), and the reopening of old tidal gullies (Baeteman 2005). As a result, the dating of this (flooding) phase in one tidal basin cannot be compared to another. Because this tidal influence creates a specific ecological landscape surrounding the Sector B and Sector M sites, dating its occurrence is a requisite to investigate the relation with the (dis-)appearance of Swifterbant culture in the region.

When the tidal influence decreased, a fen carr back-barrier lagoon shifted from eutrophic to mesotrophic conditions. As a result, the Holland peat evolved from a sedge and Sphagnum peat (Gelorini et al. 2006; Deforce 2011). Finally, a new tidal phase took place that resulted in the deposition of several meters of marine sediments ("Dunkirk deposits") and lasted until dike construction protected the alluvial plain from floods (Bogemans 1997).

\section{RECONSTRUCTING PALEOGROUNDWATER RISE BY PEAT DATING}

Because the basal peat layer that covered the well-drained Pleistocene sand was formed diachronously under the influence of rising groundwater, ${ }^{14} \mathrm{C}$ dating of samples at the base of this formation approximates the contemporaneous surfacing local groundwater (LGW) level (Figure 2). However, groundwater drainage is hampered below the mean high water (MHW) in tidal backbarrier lagoons. As a result, basal peat growth is generally initiated around the MHW level. This allows the reconstruction of the local mean high water level (LMHW) and the RSL through time, which was first applied by Jelgersma (1961). Assuming that both modern and earlier mean sea level (MSL) did not differ more than $10 \mathrm{~cm}$ between the Belgian and German North Sea coast (Kiden et al. 2008), comparison between differing LGW curves has revealed a series of influencing variables (e.g. Roeleveld 1974; Van De Plassche 1982; Van Dijk et al. 1991; Kiden 1995; Makaske et al. 2003; Van De Plassche et al. 2005, 2010; Berendsen et al. 2007; Kiden et al. 2008).

A first source of variation between RSL curves is subsidence. Tectonic subsidence is relatively small and constant throughout the Holocene $(0.008-0.15 \mathrm{~m} / \mathrm{ka}$ ) (Vink et al. 2007). Glacio-isotatic and/or hydro-isostatic subsidence is the largest source of variation between RSL curves along the North Sea coast during the Early Holocene $(\sim 2.67 \mathrm{~m} / \mathrm{ka}$ between $9-7.5 \mathrm{cal} \mathrm{ka}$ BP between BE and W-NL), but has decreased since $5000 \mathrm{cal} \mathrm{BP}(\sim 0.4 \mathrm{~m} / \mathrm{ka}$ between $7.5-5 \mathrm{cal} \mathrm{ka} \mathrm{BP})$ and is currently almost negligible (Kiden et al. 2002; Vink et al. 2007). Secondly, if the coastal barrier is opened, the tidal wave can enter the back-barrier easily; thus, the coastal MHW level equals the local MHW. 
If the gaps in the beach ridges decrease, the tidal wave is hampered and the local tidal amplitude decreases (local MHW = MSL) (Makaske et al. 2003). This tidal damping is called the flood basin effect (Van De Plassche 1982; Van De Plassche et al. 2010). On the one hand, the estuary floodplain of the Scheldt decreases in size downstream of Antwerp, creating a tidal bulge (tidal amplification). On the other hand, upstream of this bottleneck, the tidal wave is dampened, caused by the more shallow meandering Scheldt, which dissipates tidal flow into its tributaries and wider alluvial plain (tidal extinction) (Kiden 2006). Van Dijk et al. (1991) also illustrates that as a consequence of the rising MSL and increasing sedimentation, the effect of the decreasing river gradient is visible in local basal peat curves along the Rhine-Meuse (see Cohen 2003: Figure 2.3). Finally, if the riverbed cuts through its natural levees to create a more favorable river gradient, this creates a short-term increase followed by a steady decrease in the speed of local MHW rise, superimposing the long-term RSL rise (Berendsen et al. 2007).

\section{SAMPLING AND DATING}

\section{Data Collection}

A database of legacy ${ }^{14} \mathrm{C}$ dates on bulk peat samples and selected terrestrial peat macroremains was assembled from the literature (Appendix 1 [online supplemental file], Figure 1). If possible, both sample location and elevation were included. Further dates were included from a new dating program, yielding 20 new dates (Appendix 1, Figure 1). These dates were only performed on small accelerator mass spectrometry (AMS) samples of terrestrial macroremains according to Tornqvist et al. (1992). Suitable macroremains were selected by Hanneke Bos (ADC).

\section{Paleogroundwater Dates}

Samples have to be selected directly on top of the Pleistocene substratum as these are not compacted and at the original elevation. Through a series of dates at different elevations, a LGW rise curve can be constructed. The earliest peats were not necessarily formed under the influence of RSL rise because peat is also formed above MHW due to surfacing of the groundwater (groundwater gradient effect) (Van De Plassche 1982; Denys and Baeteman 1995). Therefore, sample locations with a high Pleistocene surface gradient such as Late Glacial floodplain dunes or paleovalley flanks are preferred (Van De Plassche 1982).

Various sources of error complicate the reconstruction of local groundwater rise curves using basal peat dates. Vertical errors in the age-depth plot can be introduced by several factors (Berendsen et al. 2007): the assumed depth of the sample is imprecise because of (1) sample elevation measurement ( $0.05 \mathrm{~m}$ error); (2) the in-core measurement ( $0.03 \mathrm{~m}$ error); or (3) through the sample thickness $(0.02 \mathrm{~m}$ error). Vertical errors due to compaction are minimal but can be approximated as an upward error of twice the vertical distance to the Pleistocene sand according to Van De Plassche et al. (2005). Further vertical errors are caused by the complex relationship between a basal peat sample and actual groundwater depth elevation. This is estimated to be $0.1 \mathrm{~m}$ by Makaske et al. (2003), but can vary considerably depending on the peat vegetation. For example, Phragmites grow up to $30 \mathrm{~cm}$ below the water table and were excluded, as well as rainfed Spaghnum peats (van der Spek 1997). Wood peat, on the other hand, develops closer to the local groundwater level $(0.2 \mathrm{~m}$ error). Using the method proposed by Berendsen et al. (2007), a vertical standard deviation error of $0.21 \mathrm{~m}$ was estimated.

Horizontal (age) errors can be introduced if conventional bulk dating samples are contaminated by inclusion of aquatic macroremains in the bulk sample, such as underlying older paleosols where there has been penetration by roots of younger plants. These can partially be accounted for during 
dating sample selection but are hard to estimate. Analytical errors during laboratory measurements are shown through the standard deviation value of the ${ }^{14} \mathrm{C}$ age.

\section{Calais Dates}

Dating organic remains in the Calais sediment itself would result in unreliable dates because this sediment was deposited in a mobile fluvial and/or marine environment, allowing the deposition of aquatic or older organic remains eroded from elsewhere. It is impossible to create a regional age-depth model using dates related to the tidal deposits as compaction could have caused vertical movement of the samples.

Dating the top of the basal peat directly below only provides a terminus post quem for the start of the tidal sedimentation. Age errors are introduced if the top of the basal peat is eroded (e.g. by tidal channels). On the other hand, peat marsh microtopography can introduce a later start of sedimentation than the first tidal influence in the region. Therefore, only the oldest peat dates without an erosive transition to the Calais deposits were chosen as reliable indicators for regional appearance of a tidal environment.

The end of this tidal influence was dated using peat samples located at the base of the Holland peat. It has been observed by Vos and van Heeringen (1997) that the transition from the tidal Calais sedimentation to the restart of freshwater Holland peat development is a rather slow process. Therefore, it is expected that the end of the tidal influence will be less precisely defined.

\section{Archaeological Dates}

Two archaeological sites with artifacts mainly belonging to the Swifterbant material culture were selected. The occupation of these sites has been dated using short-lived plant macroremains recovered from hearths and hearth pits directly relatable to the sites' occupation (e.g. charred hazelnuts, seeds or charcoal from twigs) (Van Strydonck 2005; Boudin et al. 2010) (Table 2).

\section{MODELING AND RESULTS}

Calibration, analysis, and Bayesian modeling of the dates were performed using OxCal v 4.2 (Bronk Ramsey 2009a) and the IntCal09 curve (Reimer et al. 2009). Other packages are also suitable to create deposition models of chronological records such as Bpeat (Blaauw and Christen 2005) or Bchron (Haslett and Parnell 2008). All three packages have been compared by Parnell et al. (2011) and have shown to have their individual (dis)advantages. OxCal is capable of modeling and querying both archaeological and geological data from different sequences. However, OxCal has the disadvantage of not including the sample thickness (Bronk Ramsey 2008) in its age-depth models while Bchron does (Parnell et al. 2008). Nevertheless, our central question was the relationship of the various peat sequences to the Swifterbant occupation of the area, for which OxCal was most amenable.

\section{Outlier Detection}

Two steps of outlier detection were employed. First, potentially erroneous dates were marked as outliers manually after critically evaluating the available context information. Secondly, outlying dates were rejected from the model, using an overall model agreement index below $60 \%$ as an outlier indicator according to Bronk Ramsey (2009b). As such, a balance was sought between rejecting dates to fit models. The remaining basal peat dates were analyzed automatically for temporal outliers in a sedimentary sequence according to Bronk Ramsey (2009b). 


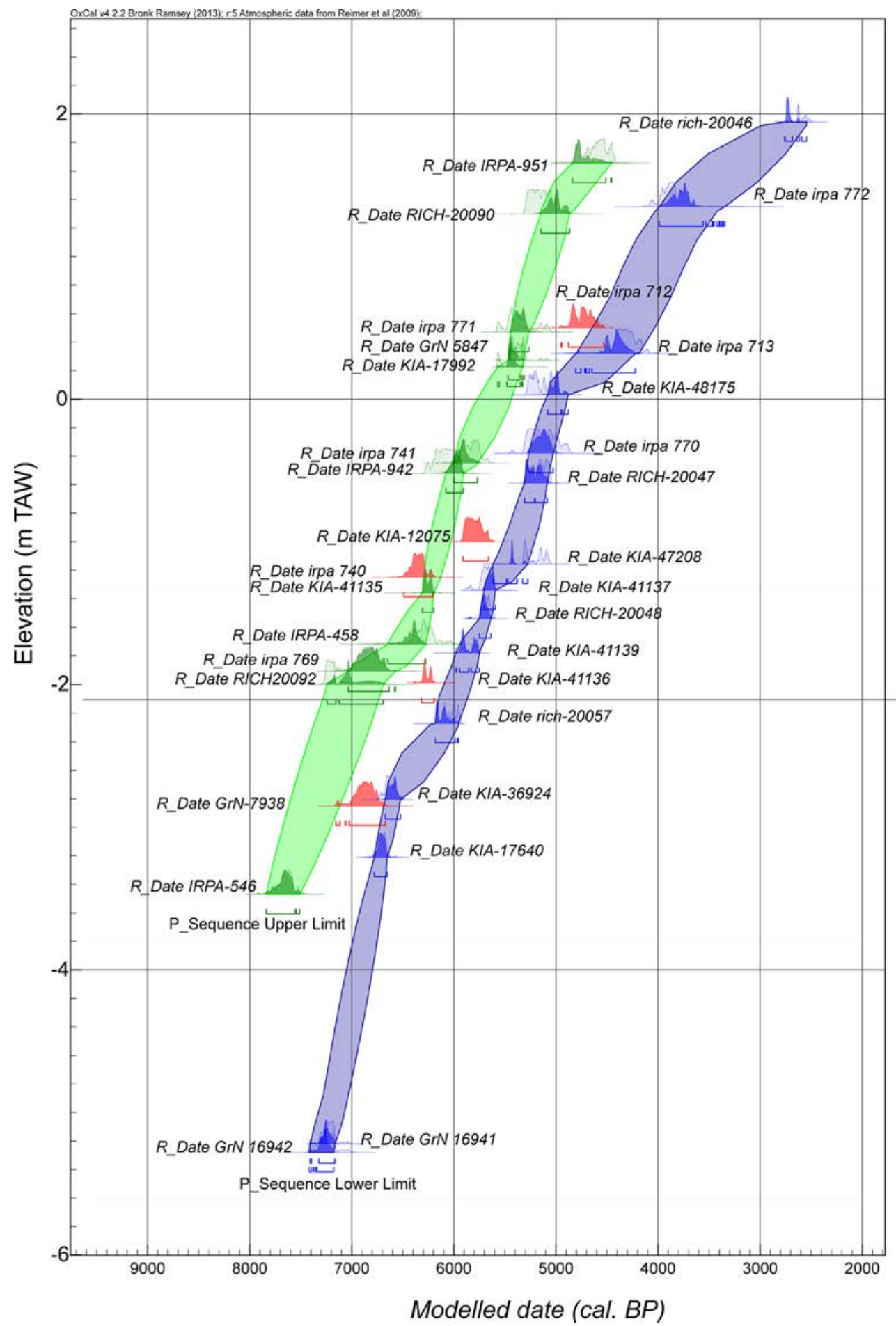

Figure 3 Age-depth plot of upper P_Sequence (green interpolation) and lower P_Sequence model (blue interpolation) enveloping the dates excluded from the sequences in between (red) (calibrated date ranges at $2 \sigma$ ). 


\section{Initiation of Peat Growth Under the Influence of Local Groundwater Rise}

Age depth modeling of basal peat growth is usually carried out for reconstructions of groundwater rise to derive RSL rise. Throughout its history, the research has been refined from models of a country's coastal plain (Jelgersma 1961) to defining the variability between single dune flanks (Cohen 2003; Berendsen et al. 2007). Such high-resolution date series were not available for the dunes surrounding the Sector B and M sites and the topographic setting of the dated samples could not always be accurately determined. Therefore, our aims were to reconstruct the spread of peat land in the regional prehistoric landscape surrounding the archaeological sites (roughly between Antwerp and the Belgian-Dutch border). The whole possible chronological and elevation range of the samples is relevant, including the regional variability in peat development, rather than merely providing a linear paleogroundwater curve. The resulting age-depth model can be considered a regional "error envelope" of the minimal and maximal age-depth of the starting peat growth.

In most publications on basal peat dating, the age-depth position of a dated sample is determined by a simple error box, defined by the date range and estimated total vertical error (e.g. Makaske et al. 2003). An advantage of the Bayesian approach allows deposition modeling of chronological records that includes both the full probability distribution function (pdf) of the ${ }^{14} \mathrm{C}$ or other dates and prior knowledge about exactly known or randomly varying sedimentation rate, stratigraphic order, or gaps in the sedimentation sequence (Bronk Ramsey 2008). Such Bayesian models have been made on peat sequences of single cores with small depth errors (Yeloff et al. 2006; Blaauw et al. 2007), but rarely have they been applied to model the diachronic evolution of a single stratigraphic position from various cores.

Unfortunately, the various local factors that influenced the determination of the elevation and time at which peat starts to develop could not entirely be included in the prior model. Thus, the initiating peat growth age-depth plot has a wide vertical and horizontal range of non-sequential dates. Constructing a single sequence including a maximal amount of data would still result in many outliers being excluded. Therefore, a minimal (upper, earlier) and maximal (lower, younger) age-depth sequence was constructed. Both sequences included as many dates as possible while reaching a sufficient overall model agreement index for upper and lower sequence of the error envelope.

First, a simple OxCal Sequence model was tested by using just the elevation of the dates as an ordering prior. This sequence was insufficient because it did not allow interpolation between dated elevations. An OxCal P_Sequence was therefore chosen because this model assumes a random deposition rate with approximate proportionality to the elevation. The degree of proportionality can be set using the $k$ parameter reflecting the number of random deposition events per $z$ unit. In this study, the latter is defined by the sample elevation but the $k$ parameter is harder to define. In a single core sequence, it can be related to the granularity of the sediments or the size of the deposition events (Bronk Ramsey 2008). This cannot be applied here because the samples do not represent accumulating peat at a single coring location. They rather refer to a possibly $0.21-\mathrm{m}($ at $1 \sigma$ ) sized age-depth point in the regional accumulation model of peat over the Pleistocene surface. As such, the $k$ parameter was set at 5 , resulting in a small proportionality between the elevation and deposition rate. Between dates, only 10 interpolated dates per meter have been calculated to limit computer processing time. If basal peat dates had been selected from a core or profile with other dated stratigraphic positions, these were included in the model using the "before" or "after" command defining additional termini ante/post quos in the prior model.

As a result, two acceptable P_Sequences could be created (Figure 4). The upper sequence included 12 dates, while 15 dates fit in a lower sequence. Four dates (KIA-41136, KIA-12075, GRN-7938, 
IRPA-712) had to be considered outliers to the upper and lower sequence. Nevertheless, they are located inside the error envelope. A fifth outlying date (IRPA-740) was statistically marked as an outlier but falls only partially outside of the error envelope.

Both the upper and lower curve show a decrease in the peat development surrounding the start between 7000 and $6500 \mathrm{cal} \mathrm{BP}$, while it increases again afterwards. This shift is attested between samples KIA-36924 from the Doel-NPP core (Deforce 2011) and RICH-20057 from Doelpolder-Noord. Both have a position on a dune flank close together on the paleovalley of the Scheldt, assuring their reliability as a groundwater indicator. In the upper P_Sequence, this shift is defined between IRPA-458, retrieved from an intact peat profile in the Doeldok (Minnaert and Verbruggen 1986), and IRPA-769 (Kiden 1989) from the slope of the Scheldt paleovalley and therefore also considered reliable indicators. The start of this decrease could possibly be related to the delaying MSL rise (Tornqvist and Hijma 2012) combined with the closing coastal beach ridges. The increase after 6500 cal BP could relate to the appearance of the tidal Calais sedimentation (see below), neutralizing a tidal damping effect possibly existing before.

The newly gathered dates between 6000 and $5500 \mathrm{cal}$ BP are filling a gap in the published dates in the Scheldt paleovalley and allow better comparison with the data from Zeeland. The lower timedepth of these dates confirms the observation by Kiden (1995) that the development of peat in the

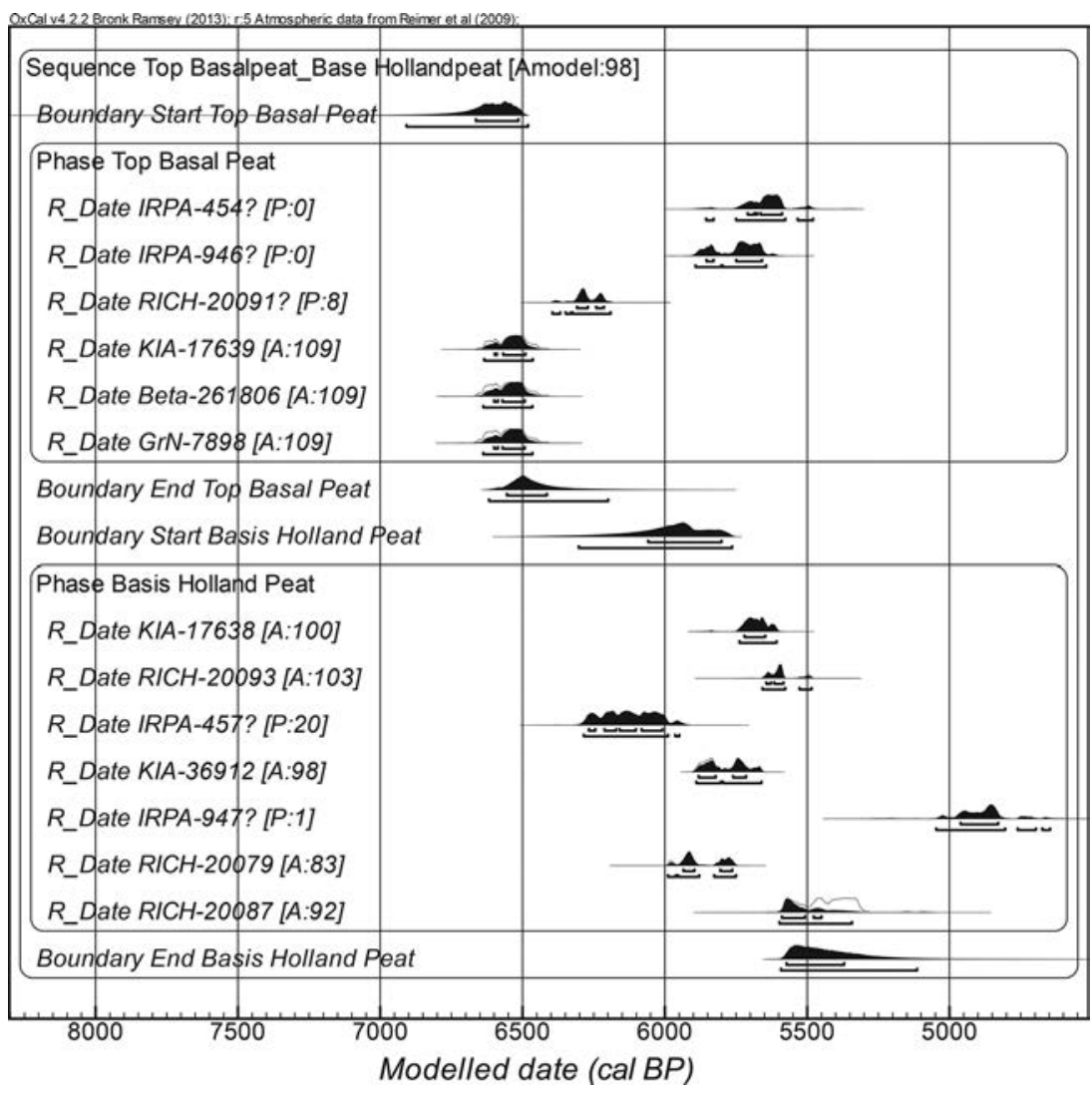

Figure 4 OxCal plot of Bayesian sequence of "Top of Basal Peat" phase dates followed by the "Basis of Holland" peat phase dates with sequential boundaries (A: agreement index; outliers: "?"; P: outlier probability). 
Scheldt Valley was more directly influenced by the effects of MSL rise than the Zeeland peat, which was developed higher due to the groundwater effect.

The size of the error envelope is probably a result of the large variability in undulating Pleistocene topography, changing flood basin, and estuary and river gradient effects. Because even dates from the same core or section fit in both sequences, it can be concluded that spatial and temporal resolution of the dates was not yet high enough to disentangle all of these more local effects as observed by Makaske et al. (2003).

\section{The Occurrence of Calais Sedimentation in the Scheldt Polders}

Inherent problems with summed probability functions to date geomorphological events have been described by Chiverrell et al. (2011). Therefore, the chronology of appearance and disappearance of the tidal Calais landscape was reconstructed using a Bayesian approach including the following a priori information.

The first assumption is that in all dated sequences the Calais sediments belonged to a single but continuous lithostratigraphic unit and that the Holland peat did not start to grow before the latest basal peat development was interrupted. Therefore, it can be assumed that the top of the basal peat is older than the base of the Holland peat. All dates belonging to the top of the basal peat are assumed to be unordered as well, allowing them to be grouped in a phase. The same was done for all dates of the base of the Holland peat. Secondly, it was assumed that the tidal influence was present during a distinct period and not a short event. As a consequence, the boundaries between both phases were modeled sequentially (Bronk Ramsey 2009a). Because the first appearance of the tidal landscape is sought, the end boundary is required from the oldest top of the basal peat dates. This boundary should refer to the event that started the expansion of tidal influence in the study area (Kiden 2006). The restart of peat growth happened as soon as this (inter-)tidal sedimentation reached a level above high water tide and tidal influence decreased. This continuous process was treated as a single broad phase. If other dates were available from the same core or profile, their stratigraphic information was included using the before and/or after function with the Calais-related datings.

Manual outlier selection excluded two samples related to the tidal clay deposits as they revealed an age inversion in the profile (IRPA-454 and IRPA-457) (Minnaert and Verbruggen 1986). Furthermore, a sample from a disturbed basal peat layer in a tidal channel (IRPA-946) (Van Strydonck et al. 1995) was considered unreliable as well. One date (IRPA-947) of the basis of the Holland peat was excluded because the pollen data indicated a hiatus between the deposition of the underlying tidal clay and the covering Holland peat (Van Roeyen et al. 1991). The remaining dates were considered reliable for the prior model. One sample from the top of the basal peat was excluded because it did not result in an sufficient model agreement index (RICH-20091). This sample was recovered near the top of an eolian sand ridge.

Using the remaining dates, a sufficient posterior model could be established (Figure 5). The end boundary of the top of the basal peat dates revealed the start of the earliest (inter-)tidal influence between 6620 and 6200 cal BP $(2 \sigma)$. Similarly, the start boundary of the base of the Holland peat revealed the renewed peat growth starting between 6300 and $5760 \mathrm{cal} \mathrm{BP}(2 \sigma)$.

The start of this sudden upstream expansion of the estuary of the Scheldt into Belgium coincides with the supposed breakthrough period of a tidal channel preceding the current Oosterschelde (Vos and van Heeringen 1997; Kiden 2006). This new estuary that broke through the coastal barrier possibly caused an increase in tidal influence, which decreased tidal damping. 
The end date range of the Calais sedimentation period is less well defined as this was probably a more complex transition. Because the study area comprises the most inland extension of the tidal influence, it was probably also among the first to be effected by the reduced tidal range and development of Holland peat.

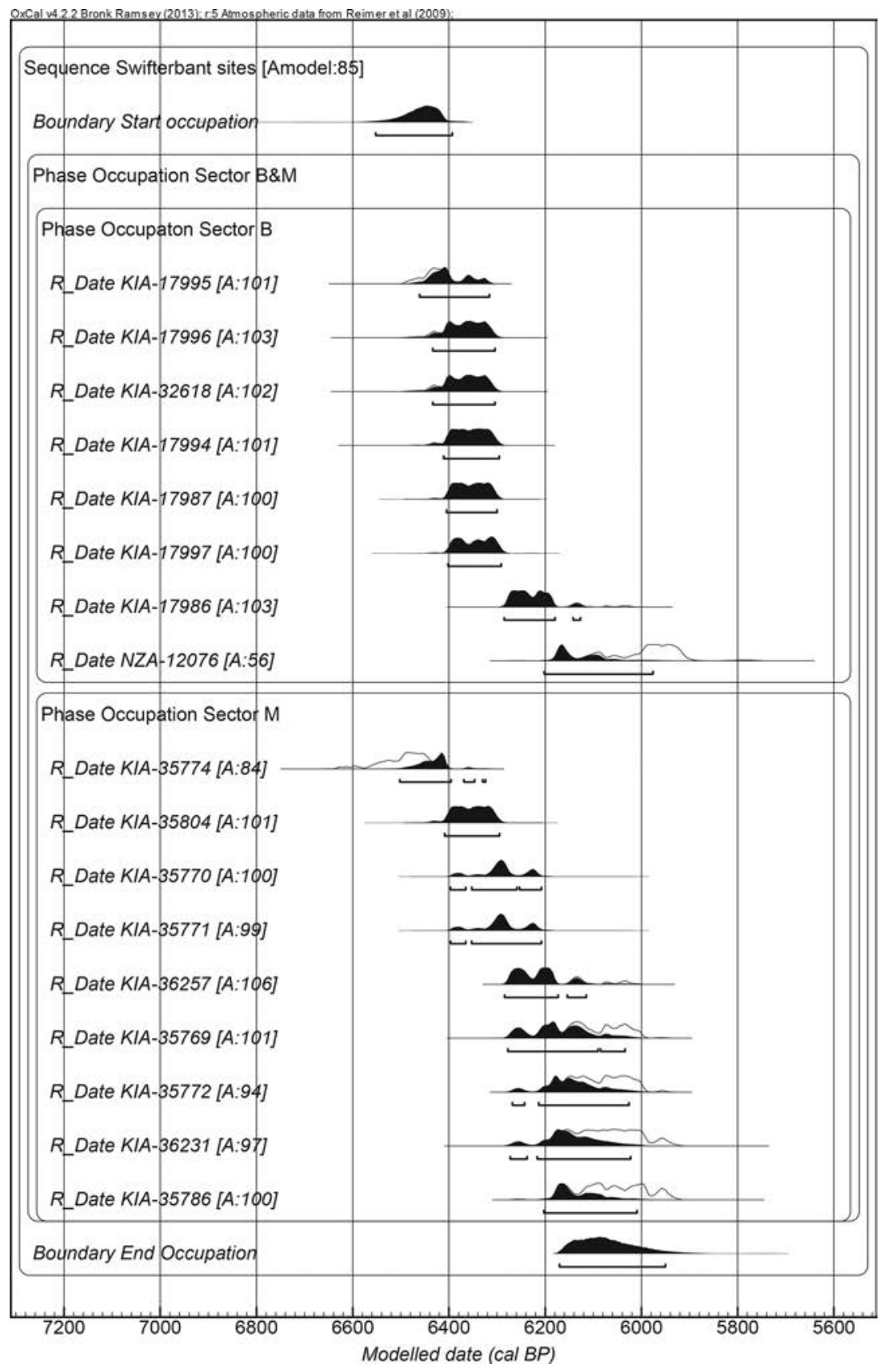

Figure 5 OxCal plot of Bayesian model of the occupation phases of Sector B and M sites (A: agreement index). 


\section{Swifterbant Culture Occupation at Sector B and M Sites}

The occupation of the Sector B and M sites has also been modeled as a single phase, consisting of two possibly overlapping subphases of Sector B and M. The start and end boundaries of the overall phase were used to estimate the start and end of Swifterbant occupation. The Bayesian modeling of the occupation revealed an individually outlying date in Sector B (NZA-12076) (Van Strydonck 2005) (Figure 6). Upon closer examination, it was found that this date was retrieved from a hearth situated higher on the sand ridge, which could be related to the peat development (see below). As a result, the posterior model of Sector B and M revealed the occupation started between 6550 and $6390 \mathrm{cal} \mathrm{BP}(2 \sigma)$ and lasted until between 6170 and $5950 \mathrm{cal} \mathrm{BP}(2 \sigma)$.

\section{Integrating the Initiation of Peat-Growth Error Envelope, the Occurrence of the Calais Landscape, and Archaeological Dates}

Integrating independently dated archaeological and geological sequence records using a Bayesian approach is rarely done (e.g. Gearey et al. 2009). This study will do so by testing correlation and order between archaeological occupation and geological events, such as individual dates or boundaries of contemporaneous phases and/or chronological sequences. The elevation of the basal peat at the start and end of Swifterbant occupation is relevant as it determines the amount of available "dry" land. However, querying a probability range of elevation values in the initiating peat growth sequences at the boundaries of the Calais sedimentation phase or Swifterbant occupation was not yet possible using $\mathrm{OxCal} v$ 4.2. Therefore, a simple plot of the archaeological dates in the basal peat age-depth model (Figure 6) was made that nevertheless revealed some key insights.

It seems that at the start of the Swifterbant occupation, the hearths were situated at least $1 \mathrm{~m}$ above the maximal envelope of the initiating peat growth. This means that the site inhabitants settled (temporarily) in the supratidal area of the floodplain, only accidently touched by tidal flooding and too highly elevated for peat development. This is confirmed by the reconstruction of an alluvial hardwood surrounding the well-drained sites (Deforce et al. 2013).

It appears that through time the rising peat caught up with the level of occupation. At that time, the tidal zone (roughly below the lower boundary of the error envelope) was still about $1 \mathrm{~m}$ below the sites. This could explain the observed gap between the end boundary of the dated hearths and the start boundary of Holland peat growth. It also shows that the end of the Swifterbant occupation at Sector B and $\mathrm{M}$ was determined by the disappearance of the tidal environment. Whether this meant the end of the Swifterbant culture in this part of the Scheldt Valley remains unclear as it could well have continued at higher topographic positions. Unfortunately, chronological evidence from higher positioned archaeological sites in the study region is currently missing (Crombé et al. 2011a).

The relationship between the (inter-)tidal Calais sedimentation and the Swifterbant occupation of the region was investigated using the OxCal correlation plot and order query functions. The correlation plot between the end boundary of the top of the basal peat and the start boundary of the Swifterbant occupation reveals a large correlation between around 6500 and 6430-6480 cal BP (Figure 7). Combined with the $61 \%$ probability that the start of the Swifterbant occupation followed the end of basal peat formation, it can be concluded that the Swifterbant occupation of the sites started shortly after the appearance of a tidal environment. This suggests that the choice to start setting up camp on the excavated sand ridges might have been at least indirectly influenced by the appearance of this tidal environment. This is further corroborated by the occupational gap between the Early Mesolithic and Swifterbant culture, attested on both sand ridges (Boudin et al. 2010). Apparently, these dunes were not attractive for occupation during the period of peat development preceding the tidal influence. 


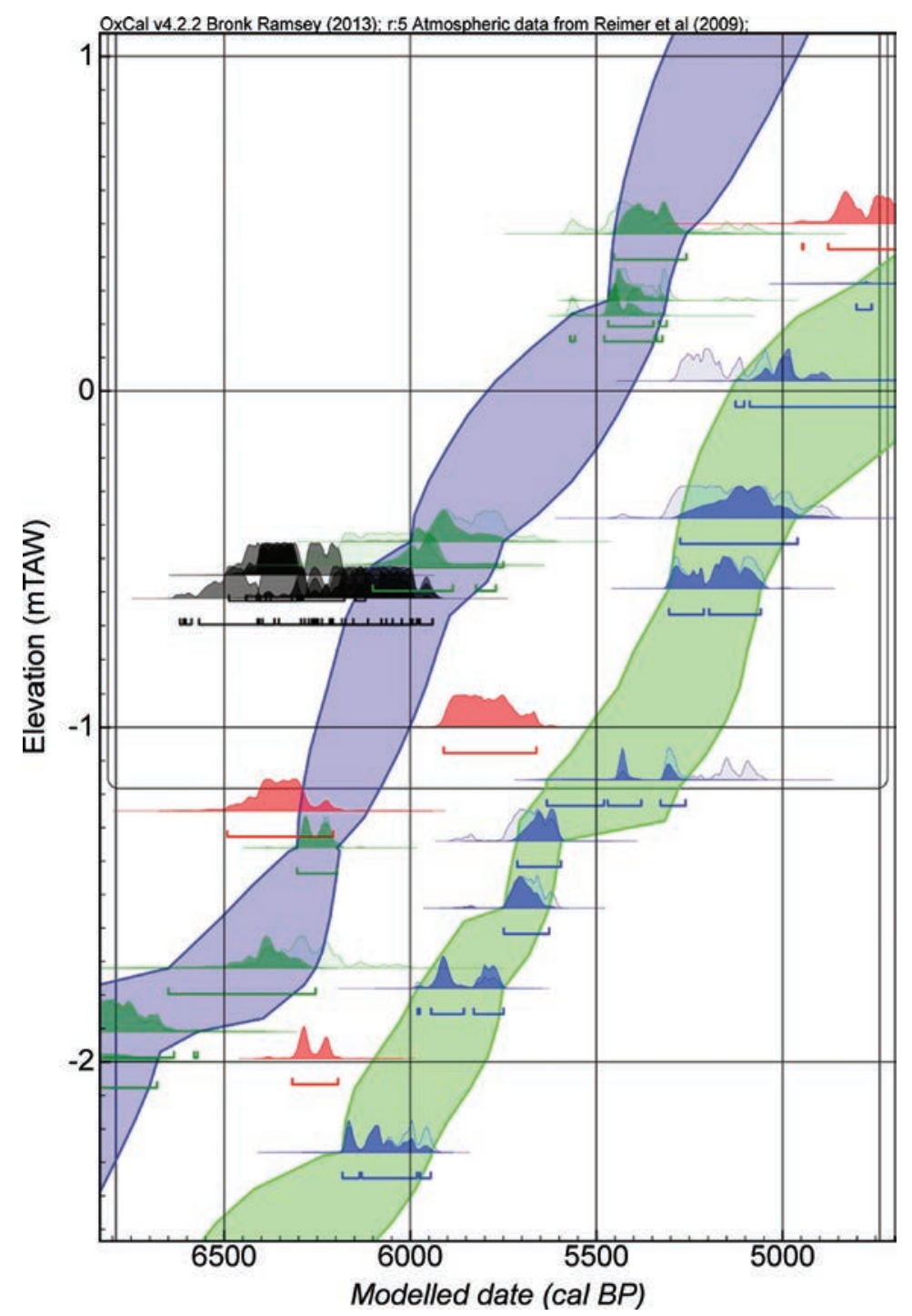

Figure 6 Detail of the basal peat curve (see Figure 3) including the archaeological Swifterbant dates (see Figure 5) (black).

A broader correlation peak indicates a lower degree of correlation between the end of Swifterbant occupation and the restart of Holland peat growth (Figure 8). In combination with an $80 \%$ probability of the Swifterbant occupation ending before peat growth restarted, it can be concluded that a gap exists between the end of the archaeological record and the disappearance of the tidal environment.

The chronological models clearly suggest that the occupation of Sector B and M happened when the tidal Calais landscape was surrounding the sites, which is further confirmed by paleobotanical and archaeozoological evidence (see earlier) (Crombé 2005; Deforce et al. 2013; Van Neer et al. 2013). These results allow the dates for site occupation to be included in a chronological sequence model between the top of the basal peat and the base of the Holland peat dates. A contiguous boundary is suitable to model the first transition samples, and a sequential transition was the optimal solution to 


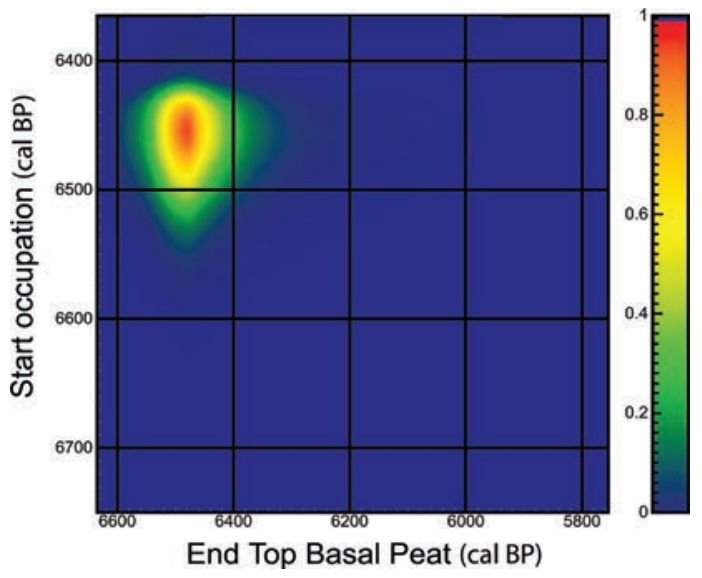

Figure 7 OxCal correlation plot of the top of basal peat growth [end boundary pdf (from Figure 4)] and Swifterbant occupation [start boundary pdf (from Figure 5)].

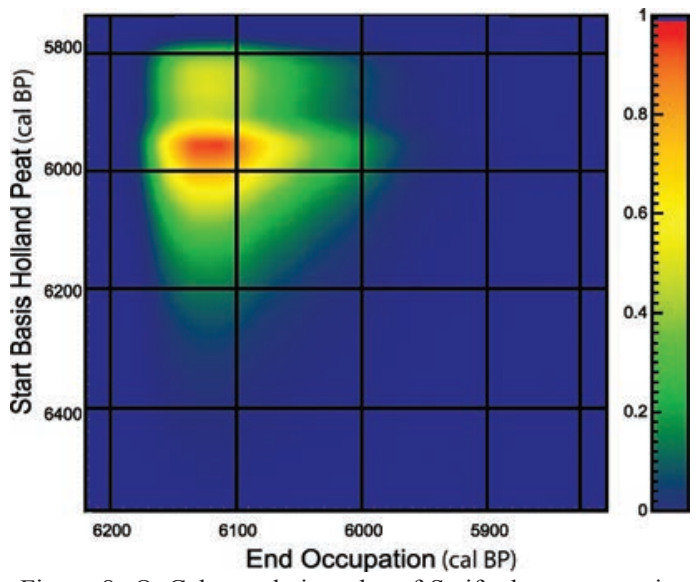

Figure 8 OxCal correlation plot of Swifterbant occupation [end Boundary pdf (from Figure 5)] against the base of Holland peat growth [start Boundary pdf (from Figure 4)].

model the gap between the Swifterbant dates and the base of the Holland peat samples. The resulting model (Figure 9) refines the boundary between the end of basal peat growth and the Swifterbant occupation between 6530 and $6410 \mathrm{cal} \mathrm{BP}(2 \sigma)$. The end of occupation is modeled between 6180 and $5980 \mathrm{cal} \mathrm{BP}(2 \sigma)$ and the restart of Holland peat growth between 6090 and $5770 \mathrm{cal} \mathrm{BP}(2 \sigma)$.

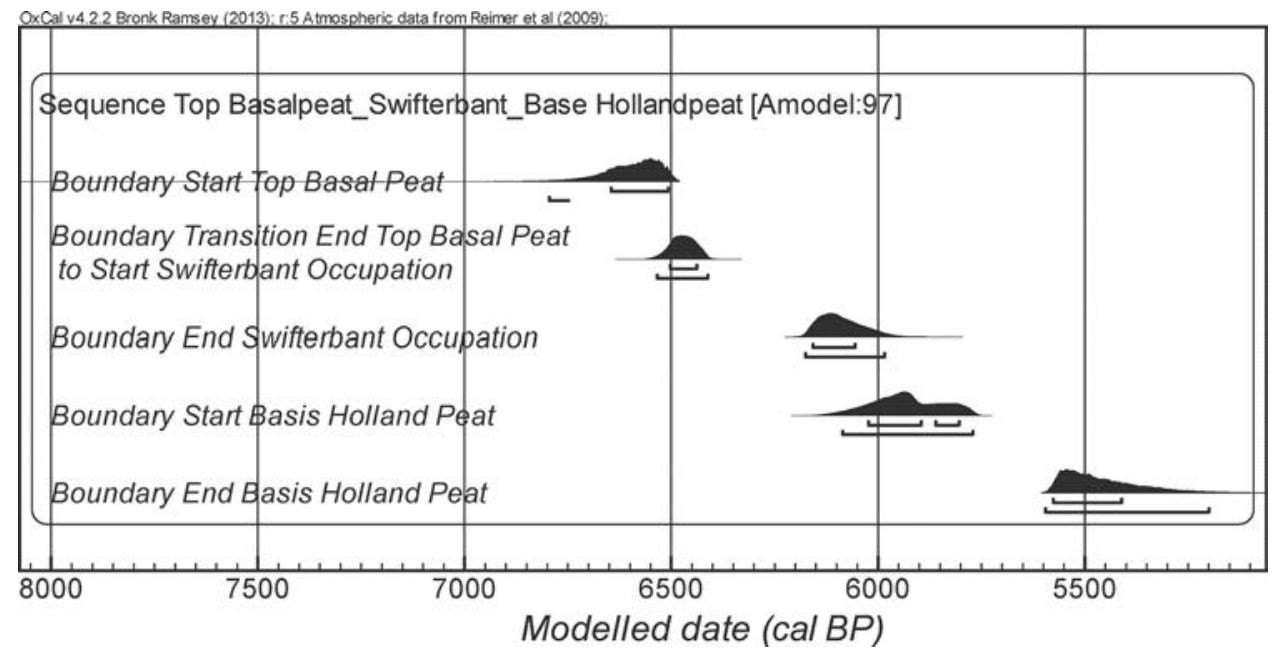

Figure 9 Bayesian model of the contiguous boundaries from a sequence of phases: top basal peat; Swifterbant occupation and base of Holland peat.

\section{CONCLUSIONS}

Regarding the first aim of this paper, the basal peat results show that a maximal error envelope for a regional model of the start of peat accumulation was obtained, using a data set of diverse origin. This model was able to add new dates to existing groundwater curves, which confirms the differing hydrological dynamics between the Scheldt paleovalley and the rest of Zeeland before they became part of the same floodplain. Further refinements could be made if high-resolution ${ }^{14} \mathrm{C}$ dating sequences of basal peat are collected, such as along separate eolian coversand ridges along the Scheldt river to study more local factors determining the initiation of peat development. 
Secondly, the sudden expansion of the tidal influence in the Scheldt River floodplain could be accurately dated and situated within the proposed timing of the development of the later Oosterschelde estuary more downstream. The end of this organic clastic environment is chronologically less sharply defined.

Finally, the near-contemporaneity of start of the (inter-)tidal influence in the region with the arrival of the Swifterbant culture at the Sector B and M sites could be proven, and further supported by tidal indications during the occupation of the sites in the archaeozoological and archaeobotanical remains (Crombé 2005; Deforce et al. 2013; Van Neer et al. 2013). The regional paleogroundwater model suggests that site occupation started well above groundwater and ended when the earliest peats could start to develop at the site. The gap between the end of the occupation of the sites and the end of the tidal influence could be explained by the retreat of the Swifterbant inhabitants to slightly higher, currently unexcavated areas.

Future applications of the results include paleogeographic landscape reconstruction at specific time intervals (e.g. Vos and van Heeringen 1997) or an interpolation including variability in three dimensions, rather than elevation only (e.g. Cohen 2003). The results also generate new research questions regarding the archaeological occupation of the alluvial plain of the lower Scheldt.

\section{ACKNOWLEDGMENTS}

The authors thank the Scientific Research Foundation Flanders (FWO) [Project title: Archaeological exploration across the land-sea boundary in the Doelpolder Noord area (Westerschelde estuary): impact of sea-level rise on the landscape and human occupation, from the prehistory to medieval times]; the Province of Antwerp-Department of Culture-Heritage Service and the City of Antwerp-Department Archaeology; and our colleague Erick Robinson for their support. The local farmers and the Flemish Nature and Forest Agency are thanked for allowing us access to their lands.

\section{REFERENCES}

Baeteman C. 2004. A discussion of Gullentops, F. \& De Moor, G. (2001): Quaternary lithostratigraphic units (Belgium). 2.2 Remaining marine-estuarine deposits. Geologica Belgica, 2001, 4/1-2:153-164. Geologica Belgica 7(1-2):77-8.

Baeteman C. 2005. How subsoil morphology and erodibility influence the origin and pattern of late Holocene tidal channels: case studies from the Belgian coastal lowlands. Quaternary Science Reviews 24(18-19):2146-62.

Bastiaens J, Deforce K, Klinck B, Meersschaert L, Verbruggen C, Vrydaghs L. 2005. Features: palaeobotanical analyses. The Last Hunter-Gatherer-Fishermen in Sandy Flanders (NW Belgium): The Verrebroek and Doel Excavation Projects, Volume 1: Palaeo-environment, Chronology and Features 3:251-78.

Beets DJ, van der Spek AFJ. 2000. The Holocene evolution of the barrier and back-barrier basins of Belgium and the Netherlands as a function of late Weichselian morphology, relative sea-level rise and sediment supply. Geologie en Mijnbouw 79(1):3-16.

Berendsen MA, Makaske B, Van De Plassche O, Van Ree MHM, Das S, van Dongen M, Ploumen S, Schoenmakers W. 2007. New groundwater-level rise data from the Rhine-Meuse delta - implications for the reconstruction of Holocene relative mean sea-level rise and differential land-level movements. Geologie en Mijnbouw 86(4):333-54.

Blaauw M, Christen JA. 2005. Radiocarbon peat chronologies and environmental change. Journal of the Royal Statistical Society: Series C (Applied Statistics) 54(4):805-16.

Blaauw M, Bakker R, Christen JA, Hall VA, van der Plicht J. 2007. A Bayesian framework for age modeling of radiocarbon-dated peat deposits: case studies from the Netherlands. Radiocarbon 49(2):357-67.

Bogemans F. 1997. Toelichting bij de Quartairgeologische kaart, kaartblad 1-7 Essen-Kapellen: Vrije Universiteit Brussel; Departement Leefmilieu, Natuur en Energie, Dienst Natuurlijke Rijkdommen, Vlaamse overheid. 38 p.

Boudin M, Van Strydonck M, Crombé P. 2009. Radiocarbon dating of pottery food crusts: reservoir effect or not? The case of the Swifterbant pottery from Doel "Deurganckdok." In: Crombé P, Van Strydonck M, Sergant J, Bats M, editors. Chronology and Evolution within the Mesolithic of North-West Europe: Proceedings of an International Meeting: Newcastle Upon Tyne: Cambridge Scholars Publishing. p 727-45.

Boudin M, Van Strydonck M, Crombé P, De Clercq W, 
van Dierendonck RM, Jongepier H, Ervynck A, Lentacker A. 2010. Fish reservoir effect on charred food residue ${ }^{14} \mathrm{C}$ dates: Are stable isotope analyses the solution? Radiocarbon 52(2):697-705.

Bronk Ramsey C. 2008. Deposition models for chronological records. Quaternary Science Reviews 27(1-2):42-60.

Bronk Ramsey C. 2009a. Bayesian analysis of radiocarbon dates. Radiocarbon 51(1):337-60

Bronk Ramsey C. 2009b. Dealing with outliers and offsets in radiocarbon dating. Radiocarbon 51(3):102345.

Chiverrell RC, Thorndycraft VR, Hoffmann TO. 2011. Cumulative probability functions and their role in evaluating the chronology of geomorphological events during the Holocene. Journal of Quaternary Science 26(1):76-85

Cohen KM. 2003. Differential subsidence within a coastal prism: Late-Glacial - Holocene tectonics in the Rhine-Meuse Delta, The Netherlands. Netherlands Geographical Studies 316:1-172.

Crombé P. 2005. The Last Hunter-Gatherer-Fishermen in Sandy-Flanders (NW Belgium). The Verrebroek and Doel Excavation Projects. Volume 1: $\mathrm{Pa}$ laeo-environment, Chronology and Features. Ghent: Universiteit Gent.

Crombé P, Sergant J, Perdaen Y. 2009. The neolithisation of the Belgian lowlands: new evidence from the Scheldt Valley. In: McCartan SB, Schulting R, Warren G, Woodman P, editors. Mesolithic Horizons. Papers presented at the Seventh International Conference on the Mesolithic in Europe. Oxford: Oxbow Books. p 564-9.

Crombé P, Sergant J, Lombaert L. 2011a. L'occupation du nord-ouest de la Belgique aux IVe et IIIe millénaires: bilan des recherches récentes en région sablonneuse. Service régional de l'archéologie en Picardie. p 103-18.

Crombé P, Boudin M, Van Strydonck M. 2011b. Swifterbant pottery in the Scheldt basin and the emergence of the earliest indigenous pottery in the sandy lowlands of Belgium. In: Hartz S, Lüth F, Terberger T, editors. Early Pottery in the Baltic - Dating, Origin and Social Context, International Workshop at Schleswig on 20-21 October 2006. Frankfurt: Bericht der Römisch-Germanischen Kommission 89. p 465-83.

Deforce K. 2011. Middle and late Holocene vegetation and landscape evolution of the Scheldt estuary. A palynological study of a peat deposit from Doel (N-Belgium). Geologica Belgica 14(3-4):277-87.

Deforce K, Bastiaens J, Van Neer W, Ervynck A, Lentacker A, Sergant J, Crombé P. 2013. Wood charcoal and seeds as indicators for animal husbandry in a wetland site during the Late Mesolithic-Early Neolithic transition period (Swifterbant culture, ca. $4600-4000$ BC) in NW Belgium. Vegetation History and Archaeobotany 22(1):51-60.

Denys L, Baeteman C. 1995. Holocene evolution of relative sea level and local mean high water spring tides in Belgium - a first assessment. Marine Geology 124(1-4):1-19.

Gearey BR, Marshall P, Hamilton D. 2009. Correlating archaeological and palaeoenvironmental records using a Bayesian approach: a case study from Sutton Common, South Yorkshire, England. Journal of Archaeological Science 36(7):1477-87.

Gelorini V, Verleyen E, Verbruggen C, Meersschaert L. 2006. Paleo-ecologisch onderzoek van een Holocene sequentie uit het Deurganckdok te Doel (Wase Scheldepolders, Noord-België). Belgeo 3:243-64.

Gullentops F, Bogemans F, De Moor G, Paulissen E, Pissart A. 2001. Quaternary lithostratigraphic units (Belgium). Geologica Belgica 4(1/2):153-64.

Haslett J, Parnell A. 2008. A simple monotone process with application to radiocarbon-dated depth chronologies. Journal of the Royal Statistical Society: Series C (Applied Statistics) 57(4):399-418.

Jelgersma S. 1961. Holocene sea level changes in the Netherlands [PhD thesis]. Leiden: Leiden University.

Kiden P. 1989. Holocene water level movements in the Lower Scheldt perimarine area. In: Baeteman C, editor. Quaternary Sea-Level Investigations from Belgium: A Contribution to IGCP Project 200. Geological Survey of Belgium. Professional Paper 1989/6(241):1-19.

Kiden P. 1995. Holocene relative sea-level change and crustal movement in the southwestern Netherlands. Marine Geology 124(1-4):21-41.

Kiden P. 2006. De evolutie van de Beneden-Schelde in België en Zuidwest-Nederland na de laatste ijstijd. Belgeo 3:279-94.

Kiden P, Denys L, Johnston P. 2002. Late Quaternary sea-level change and isostatic and tectonic land movements along the Belgian-Dutch North Sea Coast: geological data and model results. Journal of Quaternary Science 17(5-6):535-46.

Kiden P, Makaske B, Van De Plassche O. 2008. Waarom verschillen de zeespiegelreconstructies voor Nederland? Tijdschrift Grondboor en Hamer 3/4:54-61.

Louwe Kooijmans LP. 2010. Mesolithic Europe: diversity in uniformity. Antiquity 84(323):241-6.

Makaske B, van Smeerdijk DG, Peeters H, Mulder JR, Spek T. 2003. Relative water-level rise in the Flevo lagoon (The Netherlands), 5300-2000 cal. yr BC: an evaluation of new and existing basal peat time-depth data. Geologie en Mijnbouw 82(2):115-31.

Minnaert G, Verbruggen C. 1986. Palynologisch onderzoek van een veenprofiel uit het Doeldok te Doel. Buitengewone uitgaven van de Koninklijke Oudheidkundige Kring van het Land van Waas Bijdragen van de Archaeologische Dienst Waasland I 19:201-8.

Parnell AC, Haslett J, Allen JRM, Buck CE, Huntley B. 2008. A flexible approach to assessing synchroneity of past events using Bayesian reconstructions of sedimentation history. Quaternary Science Reviews 27(19-20):1872-85.

Parnell AC, Buck CE, Doan TK. 2011. A review of statistical chronology models for high-resolution, 
proxy-based Holocene palaeoenvironmental reconstruction. Quaternary Science Reviews 30(2122):2948-60.

Raemaekers DCM. 1999. The Articulation of a 'New Neolithic.' The Meaning of the Swifterbant Culture for the Process of Neolithisation in the Western Part of the North European Plain (4900-3400 BC). Leiden: Leiden University Press.

Reimer PJ, Baillie MGL, Bard E, Bayliss A, Beck JW, Blackwell PG, Bronk Ramsey C, Buck CE, Burr GS, Edwards RL, Friedrich M, Grootes PM, Guilderson TP, Hajdas I, Heaton TJ, Hogg AG, Hughen KA, Kaiser KF, Kromer B, McCormac FG, Manning SW, Reimer RW, Richards DA, Southon JR, Talamo S, Turney CSM, van der Plicht J, Weyhenmeyer CE. 2009. IntCal09 and Marine09 radiocarbon age calibration curves, $0-50,000$ years cal BP. Radiocarbon 51(4):1111-50.

Roeleveld W. 1974. The Holocene evolution of the Groningen Marine-Clay District. Berichten van de Rijksdienst voor het Oudheidkundig Bodemonderzoek 24(Supplement):8-132.

Sergant J, Perdean Y, Crombé P. 2006. The site of Doel "Deurganckdok" and the Neolithisation of the Sandy Lowland of Belgium. In: Guilaine J, van Berg JP, editors. La Neolithisation/The Neolithisation Process. Acts of the XIVth UISPP Congress, University of Ličge, Belgium, 2-8 September 2001. BAR International Series 1520. Oxford: Archeopress. p 53-60.

Tornqvist TE, Dejong AFM, Oosterbaan WA, van der Borg K. 1992. Accurate dating of organic deposits by AMS ${ }^{14} \mathrm{C}$ measurement of macrofossils. Radiocarbon 34(3):566-77.

Tornqvist TE, Hijma MP. 2012. Links between early Holocene ice-sheet decay, sea-level rise and abrupt climate change. Nature Geoscience 5(9):601-6.

Van De Plassche O. 1982. Sea-level change and water-level movements in the Netherlands during the Holocene. Mededelingen Rijks Geologische Dienst Nederland 36(1):1-93.

Van De Plassche O, Bohncke SJP, Makaske B, van der Plicht J. 2005. Water-level changes in the Flevo area, central Netherlands (5300-1500 BC): implications for relative mean sea-level rise in the Western Netherlands. Quaternary International 133-134:77-93.

Van De Plassche O, Makaske B, Hoek WZ, Konert M, van der Plicht J. 2010. Mid-Holocene water-level changes in the lower Rhine-Meuse delta (western
Netherlands): implications for the reconstruction of relative mean sea-level rise, palaeoriver-gradients and coastal evolution. Geologie en Mijnbouw 89(1):3-20.

van der Spek AJF. 1997. Tidal asymmetry and long-term evolution of Holocene tidal basins in The Netherlands: simulation of palaeo-tides in the Schelde estuary. Marine Geology 141(1-4):71-90.

Van Dijk GJ, Berendsen HJA, Roeleveld W. 1991. Holocene water level development in the Netherlands' river area; implications for sea-level reconstruction. Geologie en Mijnbouw 70:311-26.

Van Neer W, Ervynck A, Lentacker A, Bastiaens J, Deforce K, Thieren E, Sergant J, Crombe P. 2013. Hunting, gathering, fishing and herding: animal exploitation in Sandy Flanders (NW Belgium) during the second half of the fifth millennium BC. Environmental Archaeology 18(2):87-101.

Van Roeyen J-P, Minnaert G, Van Strydonck M, Verbruggen C. 1991. Melsele-Hof ten Damme: prehistorische bewoning, landschappelijke ontwikkeling en kronologisch kader. Notae Praehistoricae 11:41-9.

Van Strydonck M. 2005. Radiocarbon dating. In: Crombé $\mathrm{P}$, editor. The Last Hunter-Gatherer-Fishermen in Sandy Flanders (NW Belgium). The Verrebroek and Doel Excavation Projects (Volume 1). Ghent: Ghent University. Archaeological Reports Ghent University 3. p 127-38.

Van Strydonck M, Van Roeyen JP, Minnaert G, Verbruggen C. 1995. Problems in dating Stone-Age settlements on sandy soils: the Hof ten Damme site near Melsele, Belgium. Radiocarbon 37(2):291-7.

Vink A, Steffen H, Reinhardt L, Kaufmann G. 2007. Holocene relative sea-level change, isostatic subsidence and the radial viscosity structure of the mantle of northwest Europe (Belgium, the Netherlands, Germany, southern North Sea). Quaternary Science Reviews 26(25-28):3249-75.

Vos PC, van Heeringen RM. 1997. Holocene geology and occupation history of the province of Zeeland. Mededelingen Nederlands Instituut voor Toegepaste Geowetenschappen TNO 59:5-109.

Yeloff D, Bennett KD, Blaauw M, Mauquoy D, Sillasoo U, van der Plicht J, Geel B. 2006. High precision ${ }^{14} \mathrm{C}$ dating of Holocene peat deposits: a comparison of Bayesian calibration and wiggle-matching approaches. Quaternary Geochronology 1(3):222-35. 